\title{
Histometric Study of the Epithelium of Rats Submitted to Ethanol During Lactation
}

\author{
Estudio Histométrico del Epitelio de Ratas Sometidas al Etanol Durante la Lactancia \\ *,**Elias Naim Kassis; ${ }^{*}$ Reinaldo Azoubel; ${ }^{* * *, * * * *}$ Ruberval Armando Lopes; ${ }^{*, * *, * * * * *}$ Alex Tadeu Martins; ${ }^{* * *}$ Miguel Angel Sala di \\ Matteo \& *,***Viviane Curi Gawlinski
}

KASSIS, E. N; AZOUBEL, R.; LOPES, R. A.; MARTINS, A. T. ; DI MATTEO, M. A. S. \& GAWLINSKI, V. C. Histometric study of the epithelium of rats submitted to ethanol during lactation. Int. J. Morphol., 25(4):755-761, 2007.

SUMMARY: The present work studied the adverse effects of maternal exposure of rats to alcohol during lactation, on the development of their offspring. Histometric evaluation by karyometry and of the palatine epithelium of the sucking was performed. Two groups of animals, one coming from mothers exposed to drinking water containing $20 \%$ ethanol during the total lactation period and the other of controls coming from mothers receiving only alcohol-free drinking water during this period. On the 21 first day of lactation the young of each group were aleatorily selected and following anesthesia, their heads severed; after histological treatment, serial $6 \mu \mathrm{m}$ sections on the frontal plane at the molar level, stained with hematoxilin and eosin, were obtained. The experimental results produced, suggest that suckling from ethanol-treated mothers, show a significant decrease of body weight, significant alterations of karyometric and stereological measurements that determined hypotrophy of palatine epithelial cells and toxicity of ethanol at the palatine epithelium.

KEY WORDS: Ethanol; Palatine epithelium; Lactation.

\section{INTRODUCTION}

Consumption of alcoholic beverages by the female sex in Latin America has been increasing dramatically over the last twenty years (Veazie \& Smith, 2000). Due to complications caused at the somatic and psychic levels, as well as to deep social repercussions, it has been considered a serious public health problem (Faustino \& Stipp, 2003).

In Brazil, preliminary data obtained by the Federal University of São Paulo, Brazil, have demonstrated a 6,6\% prevalence of alcoholism in 24 counties of the State, predominantly in males, but with a $19,16 \%$ prevalence in the female population (Burgos et al., 2004).

Compared to men, alcohol reaches a higher blood concentration, and is absorbed in higher amounts thanks to the greater proportion of body fat and lesser amount of body liquid in women. Therefore, on the basis of body weights, it is more harmful to women than to men. This comparison applies only to non-pregnant women, total alcohol abstinence being recommended during pregnancy (Hochgraf et al., 1995).

Alcoholism is able to cause serious physical or mental deficiencies to fetuses during pregnancy, as well as to lead to a predisposition for drinking in adulthood (Grant, 1997). Consumption of alcoholic beverages during pregnancy is the main known cause of congenital anomalies, the fetal alcohol síndrome being one of the major consequences of its utilization during pregnancy. It occurs in approximately 2.2 of every 1000 live new-born, that present a specific pattern of congenital malformations including retardation of pre- and post-natal growth, facial dimorphism, ptosis, strabismus, short palpebral fissures, member anomalies, central nervous system dysfunction (Clarren \& Smith, 1978); microcephaly, cardiac defects

\footnotetext{
School of Medicine at São José do Rio Preto - FAMERP, Brasil.

** Post Graduation Program - Schhol of Dentistry at São José do Rio Preto - UNORP, Brasil.

*** Stomatology Department of the Faculty of Odontology of the Ribeirão Preto - USP, Brasil.

**** School of Dentistry of Franca - UNIFRAN, Brasil

****** Professor of School of Dentistry of Barretos-FEB, Brasil.

Financial Support UNIFRAN, Brasil.
} 
(Jones et al., 1973; Jones \& Smith, 1975; Hanson et al., 1976; Peiffer et al., 1979), and of neural tube (Goldstein \& Arulanantham, 1978) and renal anomalies (DeBeukelaer et al., 1977; Goldstein \& Arulanantham; Pfeiffer et al.).

Since 1983, according to Mennella \& Beauchamp (1993), has stated that alcohol must be considered a drug, that passes into maternal milk and therefore must be banned from ingestion during the whole lactation period Little et al. in 1989, have alerted to the potential of exposure to alcohol excreted into maternal milk, specially since other studies have revealed that alcoholic mothers do not change the habit of consuming alcoholic beverages during the period of lactation.

Chronic exposure to ethanol during lactation induces significant metabolic disturbances in mothers, including functional alterations of the mammary gland, leading to decreased total production of milk that in addition, contains increased lipid content (Vilaró et al., 1987). Its continuous ingestion during this phase, alters milk chemical composition (Sanchis \& Guerri, 1986; Viñas et al., 1987) resulting in the appearance of ethanol and acetaldehyde (Sanchis \& Guerri) and by exacerbation of ethanol effects in the neonate (Guerri et al., 1984).

Carmo et al. (1999) observed that in rats, maternal ingestion of alcohol, decreased milk production, causing severe malnutrition in the young, partly compensated by the milk's increased lipid content that leads to metabolic adaptation aimed at the prevention of severe hypoglycemia and the maintenance of minimal levels of hepatic glycogen. Nevertheless, such adaptation is insufficient to ensure normal brain development, usually decreased in treated animals.

Bearing in mind that maternal exposure to alcohol may cause adverse effects in rat offspring during suckling an important and vulnerable period of development, it was the aim of the present work to histometrically evaluate by karyometry and stereology, the effects of ethanol on the palatine epithelium of suckling rats. during the period of lactation.

\section{MATERIAL AND METHOD}

Animals. Ten albino female Wistar rats, weighing on an mean $200 \mathrm{~g}$, and 80 aleatorily chosen young from various litters, were kept in individual cages, receiving solid food and water ad libitum, and were aleatorily divided in two groups:
Group I constituted by 5 rats, receiving $20 \%$ ethanol in their drinking water, during the whole lactation period (21 days) plus 8 young each.

Group II constituted by the same number, of rats receiving only drinking water during the same period and in the presence of the same number of young.

Five young were aleatorily selected from each group at the end of the lactation period to become respectively, the treated and controls in this study. After weighing on a precision balance, they were sacrificed by an injection of an overdose of $3 \%$ Hypnolß .

The heads of the young were separated from their bodies, and following histological treatment and the preparation of serial $6 \mu \mathrm{m}$ sections obtained in the frontal plane at the level of the upper molars, staining with hematoxilin and eosin was performed. For karyometry, 50 nuclei each from the basal and spiny layers of the palatine epithelium from animals of the treated and control groups, were evaluated using an JENAMED optical microscope with camera lucida (JENA), under a final 1000-fold magnification; contours of the elliptical structures were drawn on white sulfite paper, with a black number 2 pencil. Using a millimeter ruler, the karyometric parameters obtained were: greatest (D) and smallest (d) diameters, mean geometric diameter, ratio of longest to shortest axis, perimeter, area, volume, ratio of volume to areas, eccentricity, shape factor, and contour index. ( Sala et al., 1994).

The same material was submitted to stereology, using the same optical microscope with a camera lucida, and the grade application preconized by Merz (1967). A projection of 20 different fields with of 100 points each, totaling 2000 points, was completed for each element of the groups. By this technique, the following parameters were obtained: volume, cellular volume, ratio of nucleus to cytoplasm, numerical cellular density and the free surface/basal layer relationship (Delesse, 1848; Chalkley, 1943; Henning, 1957).

The parameters, surface density and epithelium thickness were calculated by the Tomkeieff, 1945 and the Weibel, 1969 methods, respectively.

For statistical non-parametric analysis WilcoxonMann-Whitney test was utilized and for the mathematical calculations in the processing of the karyometric and stereological data, several computer programs of the IBMPC type, described in the Advanced Language (BASIC), set up by Maia Campos (1987) and Sala et al. (1992), from the Stomatology Department of the Faculty of Odontology, USP, Ribeirão Preto, Brazil. 


\section{RESULTS}

Table I shows that ethanol treatment of mothers leads to a statistically significant decrease of their offspring's body weight, compared to controls born from mothers not exposed to alcohol.

Table I. Mean body weights of controls and of rats born from mothers exposed to ethanol during their pregnancy, compared by the Mann-Whitney test.

\begin{tabular}{ccccc}
\hline Parameter & Controls & Treated & $\mathbf{U}$ & $\mathbf{p}[\mathbf{U}]$ \\
Body weights & $34.80 \mathrm{~g}$ & $20.20 \mathrm{~g}$ & 0 & 0.004 \\
\hline
\end{tabular}

Table II shows the statistical analysis of comparison between the cells of the palatine epithelium of control (C) and ethanol treated $(\mathrm{T})$ rats.

It can be observed that of all the karyometric parameters presented, eight (smallest and mean diameters $(\mu \mathrm{m})$, greatest-smallest diameter ratio, area $\left(\mu \mathrm{m}^{2}\right)$, volumearea ratio, eccentricity, shape factor and contour index, respectively), showed statistically significant differences between the values of control and ethanol-exposed groups.

In Table III, mean differences in nuclear parameters for nuclei of spiny layer cells of the palatine epithelium of the offspring of control and ethanol-treated mother rats.

Table II. Mean values of greatest, smallest and mean diameters $(\mathrm{mm})$, ratio between greatest and smallest diameters, volume $\left(\mu \mathrm{m}^{3}\right)$, area $\left(\mu \mathrm{m}^{2}\right)$, perimeter $(\mathrm{mm})$, volumearea ratio, eccentricity, shape factor and contour index for nuclei of basal layer cells of the palatine epithelium, of the offspring of control and ethanol-treated mother rats, compared by the Mann-Whitney test.

\begin{tabular}{lcccc}
\hline \multicolumn{1}{c}{ Parameter } & Controls & Treated & $\mathbf{U}$ & $\mathbf{p}[\mathbf{U}]$ \\
Greatest diameter & & & & \\
Smallest diameter & 5.48 & 6.21 & $0^{*}$ & 0.004 \\
Mean diameter & 8.17 & 8.59 & $2^{* *}$ & 0.016 \\
Greatest/smallest & 1.94 & 1.73 & $3^{* *}$ & 0.028 \\
Volume & 286.85 & 311.34 & $8^{\mathrm{ns}}$ & 0.210 \\
Area & 63.40 & 69.11 & $2^{* *}$ & 0.016 \\
Perimeter & 33.28 & 33.41 & $101^{\mathrm{ns}}$ & 0.421 \\
Volume-area ratio & 3.74 & 4.05 & $11^{* *}$ & 0.028 \\
Eccentricity & 0.74 & 0.72 & $4^{* *}$ & 0.048 \\
Shape factor & 0.46 & 0.54 & $0^{*}$ & 0.004 \\
Contour index & 03.87 & 3.72 & $3^{* *}$ & 0.028 \\
\hline
\end{tabular}

$* \alpha<0.01 ; * * \alpha<0.05 ; \mathrm{ns}=$ not significant
It can be observed that among the karyometric parameters presented, five (mean diameter $((\mu \mathrm{m})$, volume $\left(\mu \mathrm{m}^{3}\right)$, area $\left(\mu \mathrm{m}^{2}\right)$, perimeter and volume-area ratio, respectively), showed statistically significant differences between the values of control and ethanol-exposed groups.

Tables IV and V respectively, present the mean stereological values of the basal and spiny palatine epithelium layers of the animals evaluated in this study. Table VI presents stereologic parameters of the total epithelium.

\section{DISCUSSION}

Although Aristotle had already observed that alcoholic women gave birth to children, like themselves, taciturn and indolent (Burton, 1866); it was only after the observations of Le Moine et al. in France in 1968, and of Jones \& Smith in the United States in 1973, that the teratogenicity of maternal alcoholism became solidly established (Le Moine et al.; Jones et al.).

Consumption of alcoholic beverages by nursing mothers has been drawing the attention of researchers over the last decades, with findings related to both mothers and babies. Alcoholic beverages are considered by the U. S. Department of Health, Education and Welfare (HEW) as anesthetic and sedative drugs that pass into maternal milk already following the consumption of $1 \mathrm{~g}$ alcohol $/ \mathrm{kg} /$ day (Abel, 1964, 1974, 1978; Abel \& Dintcheff,1978).

Using histometry, the present work demonstrates, not previously published, alterations caused by ethanol in rat maternal milk, on the offspring's palatine epithelium.

Thus, the mean body weight of the newborn from mothers that had been exposed to ethanol during pregnancy, was significantly $(\mathrm{a}<0,01)$ reduced relative to that $(20.20 \mathrm{~g})$ of the young from untreated, control mothers.

This outcome agrees with the results of Abel, who in 1974, had observed that lactating animals whose mothers drank ethanol, presented significantly lower growth levels compared to controls; similarly, 
Table III. Mean values of greatest, smallest and mean diameters $((\mu \mathrm{m})$, ratio between greatest and smallest diameters, volume $\left(\mu \mathrm{m}^{3}\right)$, area $\left(\mu \mathrm{m}^{2}\right)$, perimeter $(\mathrm{mm})$, volume-area ratio, eccentricity, shape factor and contour index for nuclei of spiny layer cells of the palatine epithelium of the offspring of control and ethanol-treated mother rats, compared by the MannWhitney test.

\begin{tabular}{lcccc}
\hline \multicolumn{1}{c}{ Parameter } & Control & Treated & $\mathbf{U}$ & $\mathbf{p}[\mathbf{U}]$ \\
\hline Greatest diameter & 11.00 & 11.25 & $10^{\mathrm{ns}}$ & 0.345 \\
Smallest diameter & 7.53 & 7.84 & $6^{\mathrm{ns}}$ & 0.111 \\
Mean diameter & 8.97 & 9.36 & $4^{* *}$ & 0.048 \\
Greatest-smallest & 1.24 & 1.22 & $11^{\mathrm{ns}}$ & 0.421 \\
Volume & 553.61 & 626.20 & $4^{* *}$ & 0.048 \\
Área & 76.09 & 82.77 & $4^{* *}$ & 0.048 \\
Perimeter & 29.00 & 30.27 & $2^{* *}$ & 0.016 \\
Volume-area ratio & 5.97 & 6.24 & $4^{* *}$ & 0.048 \\
Eccentricity & 0.57 & 0.58 & $11^{\mathrm{ns}}$ & 0.421 \\
Shape factor & 0.80 & 0.79 & $6^{\mathrm{ns}}$ & 0.111 \\
Contour index & 3.06 & 3.06 & $12^{\mathrm{ns}}$ & 0.500 \\
\hline
\end{tabular}

$* * \alpha<0.05 ;$ ns $=$ not significant

Table IV. Mean stereologial values for cell and cytoplasm volumes $\left(\mathrm{mm}^{3}\right)$, the nuclear/cytoplasm ratio, thickness $(\mu \mathrm{m})$ and cell density numbers (x106) of the basal epithelium layer of the palatine of the offspring of control rats $(\mathrm{C})$ and the offspring of ethano- intoxicated rats (T). Statistical comparisons were made by the Wilcoxon - Mann-Whitney test.

\begin{tabular}{lcccc}
\hline \multicolumn{1}{c}{ Parameter } & Control & Treated & $\mathbf{U}$ & $\mathbf{p}[\mathbf{U}]$ \\
\hline Nucleus-cytoplasm ratio & 0.32 & 0.53 & $1^{* *}$ & 0.008 \\
Cytoplasm volume & 111.01 & 86.65 & $9^{\mathrm{ns}}$ & 0.274 \\
Cell volume & 397.85 & 397.99 & $11^{\mathrm{ns}}$ & 0.421 \\
Numerical cell density & 2.6 & 2.6 & $12^{\mathrm{ns}}$ & 0.500 \\
Layer thicknesss & 11.17 & 6.88 & $0^{*}$ & 0.004 \\
\hline
\end{tabular}

$* \alpha<0.01 ; * * \alpha<0.05 ; \mathrm{ns}=$ not significant;

Table V. Mean stereologial values for cell and cytoplasm volumes ( $\mathrm{mm}$ ), the nuclear/cytoplasm ratio, thickness $(\mu \mathrm{m})$ and cell density numbers $\left(\mathrm{x} 10^{6}\right)$ of the basal epithelium layer of the palatine of the offsprings of control rats (C) and of ethanol- intoxicated rats (T). Statistical comparisons were made by the Wilcoxon - Mann-Whitney test.

\begin{tabular}{lcccc}
\hline \multicolumn{1}{c}{ Parameter } & Controls & Treated & $\mathbf{U}$ & $\mathbf{p}[\mathbf{U}]$ \\
\hline Nucle us-cytoplasm ratio & 0.14 & 0.29 & $1^{* *}$ & 0.008 \\
Cytoplasm volume & 461.59 & 352.85 & $9^{\mathrm{ns}}$ & 0.274 \\
Cell volume & 1015.20 & 979.05 & $11^{\mathrm{ns}}$ & 0.421 \\
Numerical cell density & 0.98 & 1.04 & $12^{\mathrm{ns}}$ & 0.500 \\
Layer thickness & 37.83 & 13.85 & $0^{*}$ & 0.004
\end{tabular}

${ }^{*} \alpha<0.0 ;{ }^{*} \alpha<<0.05 ; \mathrm{ns}=$ not significant
Collard \& Chen, 1973 (cited by Abel, 1974 ) verified that ethanol injected into lactating mice, delayed the growth rate of their brood.

Oyama et al. (2000), observed that maternal ingestion of ethanol, affected the development of sucklings, in a dose-dependent way. Thus, the presence of $0 \%$ or $20 \%$ ethanol in the drinking water caused a decreased body weight of the young, while $5 \%$ ethanol did not cause this.

Our histometric data demonstrate by stereology that the total epithelium as well as the keratin are thinner; both were composed of more numerous cells $(p<0,01)$ but of lesser size (this difference however, was not statistically significant). Such discrimination of epithelial thickness is associated with an increased surface density $(\mathrm{p}<0,01)$, not confirmed by the higher number of cells $/ \mu \mathrm{m}^{3}$ in the total epithelium $(p<0,05)$. In treated animals, nuclei of the basal layer cells were bigger, as confirmed by the increased values, obtained karyometricaly for their smaller $(\mathrm{p}<0.01)$ and medium $(\mathrm{p}<0,05)$ diameters, area $(\mathrm{p}<0,05)$ and the $\mathrm{V} / \mathrm{A}$ ratio $(\mathrm{p}<0,05)$. A modification of the nuclear shape (eccentricity, shape coefficient $(\mathrm{p}<0.01)$ and contour index), that was more rounded, was also observed. The nuclei of spiny layer cells were also bigger by karyometry of the medium diameter $(\mathrm{p}<0,05)$, volume $(\mathrm{p}<0,05)$, area and the perimeter ratio V/A $(\mathrm{p}<0,05)$. No alteration of the form of the nuclei of the spiny layer cells occurred, in agreement with the similar values for the parameter coefficients of form and the contour index, obtained in the two groups studied. 
Table VI. Mean stereologial values for cell and cytoplasm volumes $\left(\mu \mathrm{m}^{3}\right)$, the nuclear/cytoplasm ratio, thickness $(\mu \mathrm{m})$ and cell density numbers $(\mathrm{x} 106)$ of the total epithelium layer ot the palatine of the offspring of controls (C) and of the offspring of ethanol intoxicated rats (T). Statistical comparisons were made by the Wilcoxon - Mann-Whitney test.

\begin{tabular}{lcccc}
\hline \multicolumn{1}{c}{ Parameter } & Control & Treated & $\mathbf{U}$ & $\mathbf{p}[\mathbf{U}]$ \\
\hline Surface density & 1.93 & 2.26 & $1^{* *}$ & 0.008 \\
Total epithelial thickness & 59.00 & 20.74 & $0^{*}$ & 0.008 \\
Keratin thickness & 20.93 & 12.74 & $2^{* *}$ & 0.016 \\
External surface//basal ratio & 0.956 & 2.012 & $0^{*}$ & 0.004 \\
Numerical density $\left(\mathrm{x} 10^{6}\right)$ & 1.2 & 3.6 & $0^{*}$ & 0.004 \\
\hline
\end{tabular}

$* \alpha<0.01 ; * * \alpha<0.05$

A reasonable explanation for the observed effects could be based on two mechanisms of action of ethanol; a direct one on tissues, and an indirect one due to poor nutrition in these cases.

From the point of view of a direct action, many studies have demonstrated that ethanol or its metabolite, acetaldehyde, alter protein synthesis by inhibiting hepatic transport and secretion ( Lieber, 1983, 1985). Other studies, indicated that these compounds act at the level of the microtubules (Matsuda et al., 1979; Baraona et al., 1984), causing alterations associated with intracellular accumulation of secretory vesicles and a general distension of the cistern endoplasmic reticulum (Feldman \& Maurice,1977). Although the liver is the main organ responsible for ethanol oxidation, many alterations produced by alcohol have been observed in other tissues as for exemple, poor cardiovascular function, alcohol myopathy, etc. (Klatsky, 1982).
Concerning nutritional alteration, continuous ingestion of alcohol during lactation, alters the chemical composition of milk (Sanchis \& Guerri; Viñas et al.), resulting in the appearance of ethanol and acetaldehyde (Guerri \& Sanchis, 1986), exacerbating the effects of ethanol in the newborn (Guerri et al.). Jones \& Stewart, 1984 observed decreased weight of the mammary glands as well as histological alterations in fat and epithelial cells of mammary tissue of rats that had received ethanol in their drinking water. Such structural alterations could contribute to the functional defects observed in mammary glands of animals treated with ethanol compromising their young's nutrition.

\section{CONCLUSIONS}

Based on the results of the present work, it appeared possible to conclude that $20 \%$ ethanol in drinking water administered to lactating rats, provokes the following in their suckling: a) a significant decrease of body weight; b) significant alterations of karyometric and stereological measurements that determined hypotrophy of palatine epithelial cells; c)toxicity of ethanol at the palatine epithelium.

KASSIS, E. N; AZOUBEL, R.; LOPES, R.A.; MARTINS,A.T.; DI MATTEO, M.A. S. \& GAWLINSKI, V. C. Estudio histométrico del epitelio de ratas sometidas al etanol durante la lactancia. Int. J. Morphol., 25(4):755-761, 2007.

RESUMEN: El presente trabajo tiene por objetivo estudiar en ratas los efectos adversos de la exposición materna al alcohol durante la lactancia, en el desarollo de sus crías. Fue evaluado histométricamente (cariometría y estereología) el epitelio palatino de las críass. Fueron utilizados dos grupos: uno tratado con etanol al 20\% en agua de bebedero, durante toda la lactancia; y control, recibió solamente agua. En el día $21^{\circ}$ de la lactancia, cinco crías de cada uno de los grupos, fueron seleccionadas al azar, anestasiadas las cabezas de ellas fueron separadas de los cuerpos. Después del tratamiento histológico, fueron obtenidos cortes seriados de $6 \mu \mathrm{m}$ del plano frontal, a nivel de los molares y coloreados con hematoxilina eosina. Los resultados sugieren que lactantes de las madres tratadas con etanol al $20 \%$ en el bebedero, presentaron disminución significativa del peso corporal, alteraciones importantes de las medidas cariométricas y estereológicas, que determinaron hipotrofia de las células epiteliales del paladar y toxicidad del etanol en el epitelio palatino.

PALABRAS CLAVE: Etanol; Epitelio palatino; Lactancia.

\section{REFERENCES}

Abel, E. L. Fetal alcohol syndrome and fetal alcohol effects. New York, Plenum Press, 1964. pp.183-205.
Abel, E. L. Alcohol ingestion in lactating rats: effects on mother and offspring. I. Arch. Int. Pharmacodyn. Gent (Belgium), 210:121-7, 1974. 
Abel, E. L. Effects of ethanol on pregnant rats and their offspring. Psychopharmacology, 57(1):5, 1978.

Abel, E. L. \& Dintcheff, B. A. Effects of prenatal alcohol exposure on growth and development in rats. $J$. Pharmacol. Exp. Ther. 207(3):916-21, 1978.

Baraona, E.; Finkelman, F. \& Lieber, C. S. Reevaluation of the effects of alcohol comsumption on rat liver microtubules. Res. Commun. Chem. Phatol. Pharmacol., 44(2):265-78, 1984.

Burgos, G. P. A.; Bion, M. M. \& Campos, F. Lactação e álcool: Efeitos clínicos e nutricionais. $A L A N$, 54(1):25-35, 2004.

Burton, R. (Printed under "Democritus Jr."). The Anatomy of melancholy. London,Willian Tegg, 1866. In Krous, H.F. Fetal alcohol syndrome: A dilemma of maternal. Alcoholism., 1981. V. 16.

Carmo, M. G. T. et al. Ethanol intake during lactation impairs milk production in rats and affects growth and metabolism of suckling pups. Alcohol, 18(1):71-6, 1999.

Chalkley, H. W. Metehod for the quantitative morphologic analysis of tissues. J. Natl. Cancer Just., Cary NC, 4:47-53, 1943.

Clarren, S. K. \& Smith, D.W. The fetal alcohol syndrome. N.Eng. J. Med., 298(19):1063-7, 1978.

Collard, M. E. \& Chen, C. Quart.J.Stud.Alc., 34:1323, 1973.

DeBeukelaer, M. M.; Randall, C. L. \& Stroud, D. R. Renal abnormalities in a child with fetal alcohol syndrome. J. Pediatr.,91(5):759-60, 1977.

Delesse, M. A. Procédè méchanique pour déterminer la composition des roches. Annales des Mines, 13:379-88, 1848 .

Faustino, S. E. S. \& Stipp, A. C. M. J. Appl. Oral Sci. v(1), Bauru Jan./Mar. 2003.

Feldman, G. \& Maurice, M. Morfological findings of liver protein synthesis and secretion. In Hopper H., Bianchi L., Reutter W. (Eds.). Membrane alterations as basis of liver injury. Lancaster, Engl. Med. Tech. Publ., 1977. pp. 61-76.
Goldstein, G. \& Arulanantham K. Neural tube defect and retal abnormalities in a child with fetal alcohol syndrome. J. Pediatr., 93(4):636-7, 1978.

Grant, B. F. Prevalence and correlates of alcohol use and DSM-IV alcohol dependence in the United States: results of the National Longitudinal Alcohol Epidemiologic Survey. J. Stud. Alcohol, 58(5):46473, 1997.

Guerri, C. \& Sanchis, R. Alcohol and acetaldehyde in rats milk following ethanol administration. Life Sci., 38:1543-56, 1986.

Guerri, C.; Esquifino, A.; Sanchis, R. \& Grisolia, S. Growth, enzymes and hormonal changes in offspring of alcohol-fed rats, in mechanisms of alcohol damage in utero. Ciba Foundation Symposium.,105:85-102. London, Pittman, 1984.

Hanson, J. W.; Jones, K. L. \& Smith, D.W. Fetal alcohol syndrome. Experience with 41patients. J. Am. Med. Assoc., 235(14):1458-60, 1976.

Henning, A. Fehler der Oberflachenbestimmung von Kernen bei endlicher Schnittdicke. Mikroskopie, 12(12):7-11, 1957 .

Hochgraf, P. B.; Zilberman, M. L. \& Andrade, A. G. Women alcoholics social, demographic and clinical characteristics in a Brazilian sample. Alcohol and Alcoholism., 4:427- 32, 1995.

Jones, K. L. \& Smith, D. W. The fetal alcohol syndrome. Teratology, 12(1):1-10, 1975.

Jones, K. L.; Smith D. W.; Ulleland, C. N. \& Streissguth, A. P. Pattern of malformations in offspring of chronic alcoholic mothers. Lancet, 1(7815):1267-71, 1973.

Jones, W. L. \& Stewart, D. B. Effects of orallyadministered ethanol on mammary gland morphology and functional efficiency in lactating rats. Exp. Pathol., 25:205-13, 1984.

Klatsky, A. L. The relations of alcohol and the cardiovascular system. Annu. Rev. Nutr., 2:51-71, 1982.

Le Moine, P.; Harousseau, H.; Borteyru, J. P. \& Menuet, J. C. Les enfants de parents alcooliques: Anomalies observées à propos de 127 cas. Separata de Quest. Méd., 25: 476, 1968. 
Lieber, C. S. Interactions of alcohol and nutrition. Introduction to a Symposium. Alcohol Clin. Exp. Res., 7(1):2-4, 1983.

Lieber, C. S. Metabolism of ethanol, metabolic effects and pathogenesis of injury. Acta Scand. (Suppl. 703):11, 1985.

Little, R. E. et al. Maternal alcohol use during breastfeeding and infant mental and motor development at one year. N. Engl. J. Med. 321:425-30. 1989.

Maia Campos, G. Estudo morfológico e morfométrico das malformações induzidas no feto do rato pelo consumo materno de álcool durante a gestação. São Paulo: USP, 1987 (Relatório à Comissão Especial de Regime de Trabalho-CERT).

Matsuda, Y.; Baraona, E.; Salaspuro, M. \& Lieber, C. S. Effects of ethanol on liver microtubules and Golgi apparatus. Possible role in altered hepatic secretion of plasma proteins. Lab. lnvest., 41(5):455-63, 1979.

Mennella, J. A. \& Beauchamp, G. K. Beer breast feeding, and folklore. Dev. Psychobiol., 26:459-66, 1993.

Merz, W.A. Steekenmessung an gerichteten strukturen in mikroskop und Anwendung zur Bestimmung von oberflachen volumen relationen im knochengewebe. Mikroskopie, 22(5):132-42, 1967.

Oyama, L. M.; Couto, R. C.; Couto, G. E. C.; Dâmaso, A. R. \& Oller-do-Nascimento, C. M. Ethanol intake during lactation I. Effects on dams metabolism and pups' body weight gain. Alcohol, 21:195-200, 2000a.

Oyama, L. M.; Couto, R. C.; Couto, G. E. C.; Dâmaso, A. R. \& Oller-do-Nascimento, C. M. Ethanol intake during lactation II. Effects on pups 'liver and brain metabolism. Alcohol, 1(3):201-6, $2000 \mathrm{~b}$.

Peiffer, J.; Maewzki, F.; Fishbeck, H.; Bierich, J.R. \& Volk, B. Alcohol embryo and fetopathy. Neuropathology of 3 children and 3 fetuses. $J$. Neurol. Sci., 41:125-37, 1979.

Sala, M.; Lopes R. A. \& Matheus, M. Método morfológico para análisis cuantitativa de los tejidos. Determinación de los parametros normales del hepatocito de rata. Arch. de la Fac. Med. Zaragoza, 32(1):29-31, 1992.
Sala, M.A.; Komesu, M. C.; Lopes, R. A. \& Maia Campos, G. Karyometric study for basal cell carcinoma. Brazilian Dental Journal, 5(1):11-4, 1994.

Sanchis, R. \& Guerri, C. Chronic ethanol intake in lactating rats: Milk analysis. Comp. Biochem. Physiol., 85:107-10, 1986.

Tomkeieff, S. I. Linear intercepts, areas and volumes. Nature, 155(3923):24, 1945.

Veazie, M. A. \& Smith, G.S. Heavy drinking, alcohol dependence, and injuries at work among young workers in the United States labor force. Alcoholism. Clin. Exp.Res., 24(12):1811-9, 2000.

Vilaró S.; Viñas, O.; Remasar, X. \& Herrera,E. Effects of chronic ethanol consumption on lactational performance in rat: Mammary gland and milk composition and pups'growth and metabolism. Phamacol. Biochem. Behav., 27(2):333-9, 1987.

Viñas, O. Vilaró S.; Remasar, X.; Herrera,E. et al. Effects of chronic ethanol treatment on amino acid uptake and enzyme activities in the lactating rat mammary gland. Life Sci., 40:1745-9, 1987.

Weibel, E. R. Stereological principles for morphometry in electron microscopic cytology. Int. Rev. Cytol., 26:235-302, 1969.

Correspondence to:

Prof. Dr. Reinaldo Azoubel

Faculdade de Medicina de São José do Rio Preto - SP.

Av. Brigadeiro Faria Lima, 5416

São Manoel - SJ Rio Preto

SP - BRASIL

Email:vivianecuri@hotmail.com

Received: 28-06-2007

Accepted: 30-08-2007 
